\title{
Prostate Cancer TNM Finding v8
}

National Cancer Institute

\section{Source}

National Cancer Institute. Prostate Cancer TNM Finding v8. NCI Thesaurus. Code

C140119.

A finding about one or more characteristics of prostate cancer, following the rules of the TNM AJCC v8 classification system. This classification system applies to adenocarcinomas and squamous cell carcinomas of the prostate gland. It does not apply to sarcomas, urothelial cell carcinomas, and urothelial carcinoma of bladder involving prostate. (from AJCC 8th Ed.) 